\title{
Phenotypic and genetic analysis of virulence factors in multidrug- sensitive and multidrug-resistant clinical isolates of Pseudomonas aeruginosa
}

Análise fenotípica e genética de fatores de virulência em isolados clínicos de Pseudomonas aeruginosa multidroga sensíveis e multidroga resistentes

Análisis fenotípico y genético de factores de virulencia en aislados clínicos de Pseudomonas aeruginosa sensible y resistentes a múltiples fármacos

Received: 08/30/2021 | Reviewed: 09/03/2021 | Accept: 09/04/2021 | Published: 09/06/2021

Stephanie Targino Silva
ORCID: https://orcid.org/0000-0001-6997-2623
Universidade Federal de Pernambuco, Brazil
E-mail: stephanietargino@ @otmail.com
Jailtton Lobo da Costa Lima
ORCID: https://orcid.org/0000-0002-5500-1129
Universidade Federal de Pernambuco, Brazil
E-mail: jailtonlobo@ @otmail.com
Marcelle Aquino Rabelo
ORCID: https://orcid.org/0000-0003-3176-1008
Universidade Federal de Pernambuco, Brazil
E-mail: marcellearabelo@ gmail.com
Armando Monteiro Bezerra Neto
ORCID: https://orcid.org/0000-0003-3023-4265
Universidade Federal de Pernambuco, Brazil
E-mail: monteiro.armando10@ gmail.com
Lílian Rodrigues Alves
ORCID: https://orcid.org/0000-0002-5165-9353
Universidade Federal de Pernambuco, Brazil
E-mail: profa.lilianalves@ gmail.com
Jussyêgles Niedja da Paz Pereira
ORCID: https://orcid.org/0000-0002-6494-0128
Universidade Federal de Pernambuco, Brazil
E-mail: ju-biomed@ @otmail.com
Ana Catarina de Souza Lopes
ORCID: https://orcid.org/0000-0003-0277-108X
Universidade Federal de Pernambuco, Brazil
E-mail: ana.lopes.ufpe@ gmail.com
Maria Amélia Vieira Maciel
ORCID: https://orcid.org/0000-0002-4220-6889
Universidade Federal de Pernambuco, Brazil
E-mail: amelia57@ gmail.com

\begin{abstract}
This study aimed to correlate the pattern of antimicrobial susceptibility, phenotypic production of virulence factors, the occurrence of virulence factors genes and the clonal profile of clinical isolates of Pseudomonas aeruginosa of a tertiary hospital in Recife-PE. The 30 clinical isolates (15 multidrug-sensitive (MDS) and 15 multidrug-resistant (MDR)) were analyzed using phenotypic methods to detect virulence factors (alkaline protease, hemolysin, phospholipase $\mathrm{C}$, lipase, and pigments). The detection of the aprA, lasA, las $B, p l c H$, and toxA genes was performed through specific PCRs, and the clonal profile was assessed using ERIC-PCR. The results revealed cephalosporins being the class eliciting the highest percentage of resistance; the MDR isolates were all resistant. Among the MDS isolates, all were sensitive to carbapenems and quinolones. The MDR isolates produced less virulence factors such as pyocyanin and lipase, and exhibited lower expression of toxA and las $A$ genes, whereas the MDS isolates produced less hemolysin and phospholipase $\mathrm{C}$. There was no difference between the groups for alkaline protease production and aprA gene expression. All the isolates produced pyocyanin and expressed las $B$ and $p l c H$ genes. A great genetic diversity was found, and it was possible to observe 28 genetic profiles. Clones were present among the MDR isolates. The occurrence of virulence factors in almost all the isolates studied suggests their high level of pathogenicity, demonstrating that this pathogen is capable of accumulating numerous virulence factors, and in some cases, is associated with multidrug resistance, which makes it difficult to treat these infections.
\end{abstract}

Keywords: Pseudomonas aeruginosa; Virulence; Antibiotic resistance. 


\section{Resumo}

Este estudo teve como objetivo correlacionar o padrão de suscetibilidade aos antimicrobianos, a produção fenotípica de fatores de virulência, a ocorrência de genes de fatores de virulência e o perfil clonal de isolados clínicos de Pseudomonas aeruginosa de um hospital terciário de Recife-PE. Os 30 isolados clínicos (15 multidroga sensíveis (MDS) e 15 multidroga resistentes (MDR)) foram analisados usando métodos fenotípicos para detectar fatores de virulência (protease alcalina, hemolisina, fosfolipase $\mathrm{C}$, lipase e pigmentos). A detecção dos genes aprA, las $A$, las $B$, plcH e toxA foi realizada por meio de PCRs específicos e o perfil clonal avaliado por ERIC-PCR. Os resultados revelaram que as cefalosporinas são a classe com a maior percentagem de resistência; os isolados MDR eram todos resistentes. Entre os isolados de MDS, todos foram sensíveis a carbapenêmicos e quinolonas. Os isolados MDR produziram menos fatores de virulência, como piocianina e lipase, e exibiram menor expressão dos genes toxA e lasA, enquanto os isolados MDS produziram menos hemolisina e fosfolipase C. Não houve diferença entre os grupos para produção de protease alcalina e expressão do gene aprA. Todos os isolados produziram piocianina e expressaram os genes las $B$ e $p l c H$. Foi encontrada uma grande diversidade genética, sendo possível observar 28 perfis genéticos. Os clones estavam presentes entre os isolados MDR. A ocorrência de fatores de virulência em quase todos os isolados estudados sugere seu alto índice de patogenicidade, demonstrando que esse patógeno é capaz de acumular inúmeros fatores de virulência e, em alguns casos, está associado à multirresistência, o que dificulta o tratamento dessas infecções.
\end{abstract}

Palavras-chave: Pseudomonas aeruginosa; Virulência; Resistência a antibióticos.

\title{
Resumen
}

Este estudio tuvo como objetivo correlacionar el patrón de susceptibilidad a los antimicrobianos, la producción fenotípica de factores de virulencia, la aparición de genes de factores de virulencia y el perfil clonal de aislados clínicos de Pseudomonas aeruginosa de un hospital terciario de Recife-PE. Los 30 aislados clínicos (15 sensibles a múltiples fármacos (MDS) y 15 resistentes a múltiples fármacos (MDR)) se analizaron mediante métodos fenotípicos para detectar factores de virulencia (proteasa alcalina, hemolisina, fosfolipasa $\mathrm{C}$, lipasa y pigmentos). La detección de los genes aprA, lasA, lasB, plcH y toxA se realizó mediante PCR específicas y se evaluó el perfil clonal mediante ERIC-PCR. Los resultados revelaron que las cefalosporinas son la clase con mayor porcentaje de resistencia; Todos los aislados de MDR fueron resistentes. Entre los aislados de MDS, todos fueron sensibles a carbapenémicos y quinolonas. Los aislados de MDR produjeron menos factores de virulencia, como piocianina y lipasa, y mostraron una menor expresión de los genes toxA y lasA, mientras que los aislados de MDS produjeron menos hemolisina y fosfolipasa C. No hubo diferencias entre los grupos para la producción de proteasa alcalina y la expresión génica de aprA. Todos los aislados produjeron piocianina y expresaron los genes las $B$ y $p l c H$. Se encontró una gran diversidad genética, siendo posible observar 28 perfiles genéticos. Los clones estaban presentes entre los aislados de MDR. La ocurrencia de factores de virulencia en casi todos los aislamientos estudiados sugiere su alto índice de patogenicidad, demostrando que este patógeno es capaz de acumular numerosos factores de virulencia y, en algunos casos, se asocia a multirresistencia, lo que dificulta el tratamiento de estas infecciones.

Palabras clave: Pseudomonas aeruginosa; Virulencia; Resistencia antibiótica.

\section{Introduction}

Pseudomonas aeruginosa, one of the main pathogens involved in hospital infections of immunocompromised patients, causes the most frequent healthcare-related infections associated with drug-resistant bacteria. This bacterium is considered an opportunistic infectious agent and exhibits several pathogenic mechanisms as well as resistance to various antimicrobials (PazZarza et al., 2019).

It is one of the six pathogens in the ESKAPE group (comprising Enterococcus faecium, Staphylococcus aureus, Klebsiella pneumoniae, Acinetobacter spp., P. aeruginosa, and Enterobacter spp.) and one of the main causes of healthcarerelated infections in the United States and worldwide, owing to its ability to become resistant to available antimicrobials (Lupo, Haenni \& Madec, 2018).

Its mechanisms of resistance to antimicrobials can be intrinsic or acquired, and are related to therapeutic failure for infections related to it (Silva Júnior et al., 2017). Combinations of these resistance mechanisms have given rise to multidrugresistant (MDR) isolates (Magiorakos et al., 2012). Adding to the lack of perspectives for the introduction of new drugs that could be used against this pathogen, such evolutions provided the need for investigations on its physiology, mainly with regard to its diverse virulence factors that also contribute to the pathogenic potential of the infectious process, since they favor 
infection by increasing tissue damage and protecting $P$. aeruginosa against recognition by the immune system and the action of antimicrobials (Todar, 2020).

Moreover, some studies have shown a high percentage of virulence factors in isolates of P. aeruginosa. In a study carried out in China (Wang et al., 2013), approximately $80 \%$ of the isolates studied produced elastase, pyocyanin, and alkaline protease. In Brazil, Jácome et al. (2012) got similar results (34.4\% mucous colonies, 70.5\% pyocyanin producers, $93.4 \%$ gelatinase producers, and $72.1 \%$ hemolysin producers); in relation to the resistance pattern, $54.1 \%$ of the isolates were MDR and $4.9 \%$ were pandrug-resistant.

A study carried out in Poland by Deptuła \& Gospodarek (2010) revealed that MDR strains produced lower lipase, elastase, phospholipase C, and pyocyanin amounts compared to multidrug-sensitive (MDS) strains, and that there were no significant differences in alkaline protease activity, indicating that $P$. aeruginosa MDR strains were less virulent than MDS strains. However, the study was limited to phenotypic research of these virulence factors, and the genes responsible for their production have not been confirmed. It is also important to note that the study was carried out with isolates from a single hospital in Poland; taking into account the diversity of P. aeruginosa profiles found in different regions, local studies are necessary.

Therefore, this study aimed to describe the correlation between the presence of virulence factors, through phenotypic analysis of alkaline protease, lipase, phospholipase $\mathrm{C}$, hemolysin, and pigments; occurrence of aprA, lasA, lasB, plcH, and toxA genes; pattern of resistance to antimicrobials (multidrug sensitivity or resistance); genetic variability; and origin of clinical isolates of $P$. aeruginosa.

\section{Methodology}

\section{Bacterial Isolates}

The number of isolates for this study was convenience sample thus thirty bacterial isolates of P. aeruginosa from samples obtained at public hospitals in Recife, Pernambuco, were analyzed. The isolates were biochemically identified, subjected to antimicrobial susceptibility tests that were evaluated using the automated BD Phoenix system (CLSI, 2015), and frozen in $20 \%$ glycerol at $-20{ }^{\circ} \mathrm{C}$ in the bacteriology library of the Bacteriology and Molecular Biology Laboratory of the Department of Tropical Medicine of the Federal University of Pernambuco (UFPE). The isolates were selected by nonprobabilistic, according to their susceptibility profiles and classified according to CLSI (2015) into MDS and MDR, with a total of 15 isolates per group.

For analysis, the isolates were reactivated after inoculation in Brain Heart Infusion (BHI) broth and incubated for 24 to $48 \mathrm{~h}$ in an oven at $37{ }^{\circ} \mathrm{C}$. After bacterial growth, the isolates were seeded on cetrimide agar, which is selective for the isolation of $P$. aeruginosa, and were also cultivated on nutrient agar to conserve them in stock.

\section{Analysis of Antimicrobial Susceptibility Profile}

The isolates were tested against the following antimicrobials according to their classes, using the automated BD Phoenix system (CLSI, 2015): cephalosporins (ceftazidime (CAZ), cefepime (CPM), cefotaxime (CTX), and ceftriaxone (CRO)), carbapenemics (imipenem (IMP) and meropenem (MPM)), quinolones (ciprofloxacin (CIP), norfloxacin (NOR), and ofloxacin (OFX)), macrolides (azithromycin (ATM), $\beta$-lactam $+\beta$-lactamase inhibitor, and ticarcillin + clavulanic acid (TAC)), and aminoglycosides (gentamicin (GEN) and amikacin (AMI)). Isolates that were resistant to less than three classes of antimicrobials were classified as MDS, and those resistant to three or more classes as MDR, as carried out by Deptuła \& Gospodarek (2010). 


\section{Phenotypic Detection of Virulence Factors}

\section{Pigment Production}

Pigment (pyocyanin, pyoverdine, pyorrubin and pyomelanin) production was evaluated by observing the color corresponding to each pigment presented in the culture medium (cetrimide agar) after $24 \mathrm{~h}$ of incubation at $37{ }^{\circ} \mathrm{C}$. Moreover, the production of pyoverdine was confirmed when the cultures emitted fluorescence upon exposure to ultraviolet light (Winn Jr et al., 2008).

\section{Hemolysin Production}

To evaluate hemolysin production, isolates were seeded on blood agar and incubated for $24 \mathrm{~h}$ at $37{ }^{\circ} \mathrm{C}$. The isolates with a translucent halo around the colonies, indicating hemolysis, were considered hemolysin producers (Winn Jr et al., 2008).

\section{Alkaline Protease Production}

Alkaline protease production research was carried out according to the Jagger, Bahner \& Warren (1983) method: Isolates were inoculated with skim milk agar $(2 \%)$ and incubated at $37{ }^{\circ} \mathrm{C}$ for $24 \mathrm{~h}$. The presence of a translucent halo around the colonies was interpreted as a positive result, and the absence of this halo as a negative result. The reference strain $P$. aeruginosa ATCC 15692 (PA01) was used as a positive control.

\section{Phospholipase C Production}

To determine phospholipase C production, the method described by Habermann \& Hardt (1972) was used, with modifications. Isolates were inoculated in spots on plates containing trypticase soy agar (TSA) enriched with 10\% (vol/vol) egg yolk solution with tellurite. The plates were then incubated in an oven for $24 \mathrm{~h}$ at $37{ }^{\circ} \mathrm{C}$. The production of a black precipitate in the growth zone signaled a positive result for the production of phospholipase C. The reference strain $P$. aeruginosa ATCC 15692 (PA01) was used as a positive control.

\section{Lipase Production}

Lipase production was determined according to the method described by Janda \& Bottone (1981). Isolates were inoculated in TSA enriched with $1 \%$ Tween 80 and incubated at $37{ }^{\circ} \mathrm{C}$ for $24 \mathrm{~h}$. The formation of a cloudy halo around the growth zone was considered positive for the production of lipases, and the absence was considered negative. The reference strain P. aeruginosa ATCC 15692 (PA01) was used as a positive control.

\section{Gene Virulence Detection}

PCR reactions were performed as described by Lanotte et al (2004) and Lomholt, Poulsen \& Kilian (2001) with modifications. The primers are described in Table 1. The amplification reactions were performed in a final volume of $25 \mu \mathrm{L}$ containing $10 \mathrm{ng}$ of DNA, $0.2 \mathrm{mM}$ of dNTP, 20 pmol of each primer, $2 \mathrm{mM} \mathrm{MgCl}_{2}$, and $1.0 \mathrm{U}$ Taq DNA polymerase in $5 \times$ reaction buffer. The DNA was amplified in a thermocycler using the following protocol: initial denaturation at $94{ }^{\circ} \mathrm{C}$ for $3 \mathrm{~min}$, 30 cycles of denaturation at $94{ }^{\circ} \mathrm{C}$ for $30 \mathrm{~s}$, annealing at $55^{\circ} \mathrm{C}$ for $1 \mathrm{~min}$, and extension at $72{ }^{\circ} \mathrm{C}$ for $1 \mathrm{~min} 30 \mathrm{~s}$, and then a final extension at $72{ }^{\circ} \mathrm{C}$ for $5 \mathrm{~min}$. Each gene was amplified separately. An exception to the described protocol was made for the aprA gene, for which a ring temperature of $62{ }^{\circ} \mathrm{C}$ was used. The PCR products were subjected to electrophoresis in $1 \%$ agarose gel, stained with blue-green dye $(0.05 \mu \mathrm{g} / \mathrm{mL})$ at $100 \mathrm{~V}$ for $30 \mathrm{~min}$, detected by UV transillumination, and photo-documented. Pseudomonas aeruginosa strain ATCC 15692 (PA01) was used as a positive control. 
Table 1: Primers Sequences to research virulence genes.

\begin{tabular}{|c|c|c|c|}
\hline GENES & PRIMERS & BASE PAIR (bp) & REFERENCE \\
\hline aprA & $\begin{array}{l}\text { F (5'-GTCCTATACCGTCGACCAGGC-3') } \\
\text { R (5'-GTCGCTACCCGAGCCGCCGAT-3') }\end{array}$ & 928 & Lomholt, Poulsen \& Kilian (2001) \\
\hline las $A$ & $\begin{array}{l}\text { F (5'-CGCCATCCAACCTGATGCAAT-3') } \\
\text { R (5'-AGGCCGGGGTTGTACAACGGA-3'), }\end{array}$ & 514 & Lomholt, Poulsen \& Kilian (2001) \\
\hline las $B$ & $\begin{array}{l}\text { F (5'-GGAATGAACGAAGCGTTCTC-3' } \\
\text { R (5'-GGTCCAGTAGTAGCGGTTGG-3') }\end{array}$ & 300 & Lanotte et al., 2004 \\
\hline plcH & $\begin{array}{l}\text { F(5'-GAAGCCATGGGCTACTTCAA-3') } \\
\text { R (5'-AGAGTGACGAGGAGCGGTAG-3') }\end{array}$ & 307 & Lanotte et al., 2004 \\
\hline toxA & $\begin{array}{l}\text { F (5'-GGTAACCAGCTCAGCCACAT-3') } \\
\text { R (5'-TGATGTCCAGGTCATGCTTC-3') }\end{array}$ & 352 & Lanotte et al., 2004 \\
\hline
\end{tabular}

Source: Authors.

\section{Clonal Profile}

Clonal relationship was determined using the ERIC-PCR technique, with a volume of $25 \mu \mathrm{L}$ per tube containing 100 ng of bacterial DNA, 10 pmol of the primers (ERIC-1: 5'-ATGTAAGCTCCTGGGGATTCAC-3'; ERIC-2: 5'AAGTAAGTGACTGGGGTGAGCG-3') (Duan et al., 2009), $1 \times$ buffer, $200 \mu \mathrm{M}$ DNTPs, $1.5 \mu \mathrm{L} \mathrm{MgCl}_{2}$, and 1 U Taq DNA polymerase. The parameters of the PCR were as follows: initial denaturation at $95{ }^{\circ} \mathrm{C}$ for $3 \mathrm{~min}$, followed by 30 cycles of 92 ${ }^{\circ} \mathrm{C}$ for $1 \mathrm{~min}$, annealing at $36{ }^{\circ} \mathrm{C}$ for $1 \mathrm{~min}$, and extension at $72{ }^{\circ} \mathrm{C}$ for $8 \mathrm{~min}$, and finally, $16 \mathrm{~min}$ at $72{ }^{\circ} \mathrm{C}$. The products were stained with blue-green dye and subjected to electrophoresis in $1.5 \%$ agarose gel, visualized under UV light, and photodocumented. Data analysis and construction of the dendrogram were performed using Past.exc software.

\section{Results}

\section{Bacterial Isolates}

Related the origin of the sample of the bacterial isolates, $50 \%$ the source was tracheal secretions, $20 \%$ from urine and blood, with the catheter tip being the site of least origin from the isolates, $7 \%$.

\section{Analysis of the profile of susceptibility to Antimicrobials}

The data of the susceptibility profile are shown in Figure 1. The highest percentages of resistance (considering resistant and intermediate results) were observed among cephalosporins, 50\% ceftazidime (15/30), while norfloxacin, presented the lowest frequency of resistant isolates $16.67 \%(5 / 30)$.

Figure 1. Antimicrobial susceptibility profile of clinical isolates of P. aeruginosa.

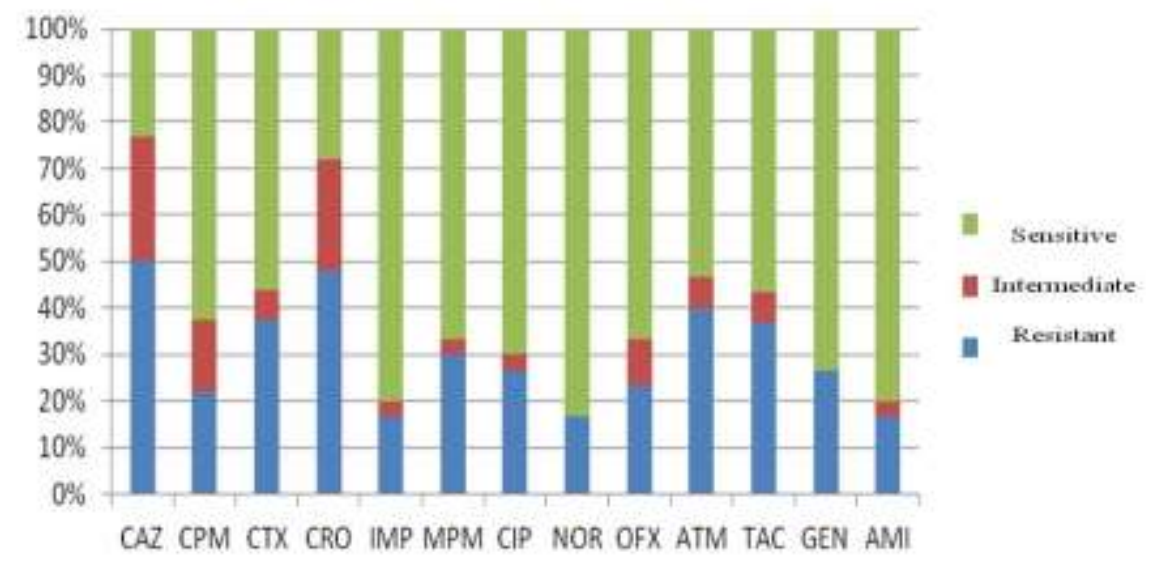

Source: Authors. 
The frequency of resistance to the antimicrobial classes between MDS and MDR isolates is shown in Figure 2, and the distribution of the frequency of the isolates according to the number of classes to which they were resistant is described in Table 2. It is noted that among MDS isolates there was a higher frequency of isolates resistant to cephalosporin $66.67 \%$ $(10 / 15)$ and all isolates tested were sensitive to carbapenems and quinolones, and among MDR isolates all isolates showed resistance to the cephalosporin class, and a lower frequency of resistance to aminoglycosides 53.34\% (8/15).

Figure 2. Frequency resistance profile of antimicrobials class among MDS and MDR isolates P. aeruginosa.

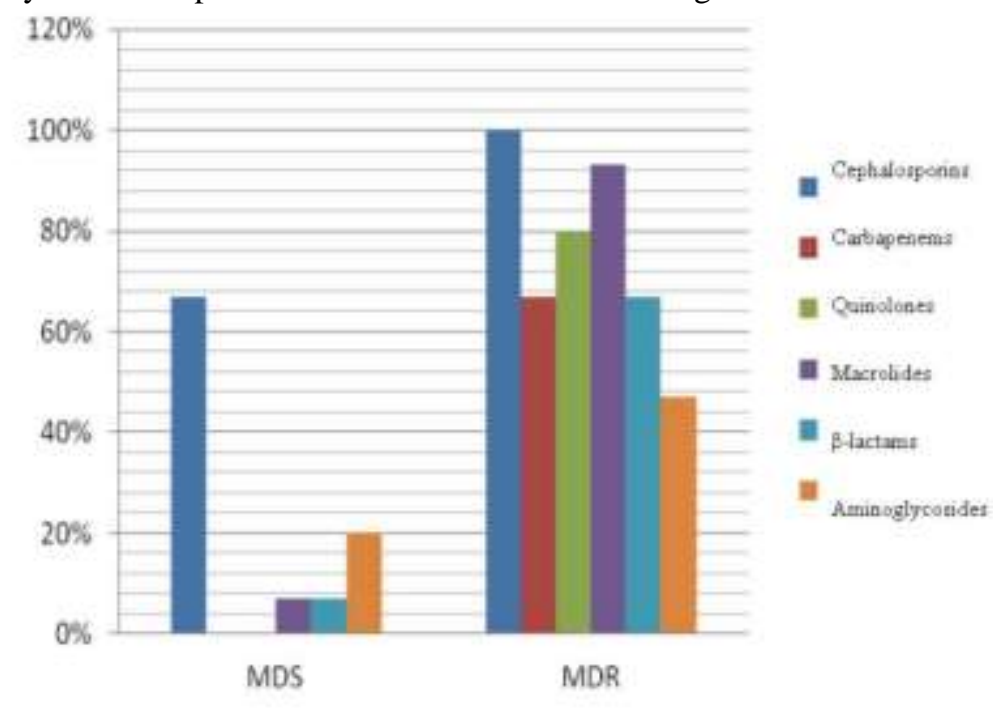

Source: Authors.

Table 2. Resistant isolates frequency corresponding to the number of antimicrobial classes tested.

\begin{tabular}{lcc}
\hline MDS & N & $\%$ \\
\hline Sensitive to all classes & 53.4 \\
Resistant to 1 class & 53.4 \\
Cephalosporins & \\
Resistant a 2 class & 3 & 20 \\
Cephalosporin + Aminoglycosides & 1 & 6.7 \\
Cephalosporin + Macrolides & 6.7 \\
Cephalosporin + $\beta$-lactams & 1 & 100 \\
\hline Total $\quad$ & 5 \\
\hline Resistant to 3 classes & 3 \\
Cephalosporin + Carbapenems + Macrolides & 1 & 6.7 \\
Cephalosporin + Carbapenems + Quinolones & 20 \\
Resistant to 4 classes & 2 \\
Cephalosporin + Quinolones + + $\beta$-lactams & 13.4 \\
Cephalosporin + Carbapenems + Quinolones + Macrolides & 6.7 \\
Resistant to 5 classes & 1 \\
Cephalosporin+Carbapenems+Quinolones+Macrolides+ & 3 \\
Aminoglycosides & 20
\end{tabular}




\section{Phenotypic detection of virulence factors}

Regarding the phenotypic search for virulence factors pyocyanin, pyoverdine, pyomelanin, hemolysin, protease, lipase and phospholipase $\mathrm{C}$, the results are described in nominal form (present/absent of the virulence factor), and are shown in Figure 3. There was a higher production of phospholipase among MDR isolates and related the MDS isolates there was a higher production of lipase.

The production of bacterial pigment pyorubin was not observed in any of the groups analyzed. Pyomelanin was observed in sensitive isolates, but in a low percentage, and pyocyanin pigment was present in sensitive and antimicrobial resistant isolates, and in relation to pyoverdine it was produced in both groups, this pigment being described in $100 \%$ of the isolates. The difference between the production of hemolysin in the two groups it was low and protease factor were frequently elevated in both groups.

Figure 3. Frequency of virulence phenotypes of clinical isolates of $P$. aeruginosa according to the MDS and MDR resistance pattern.

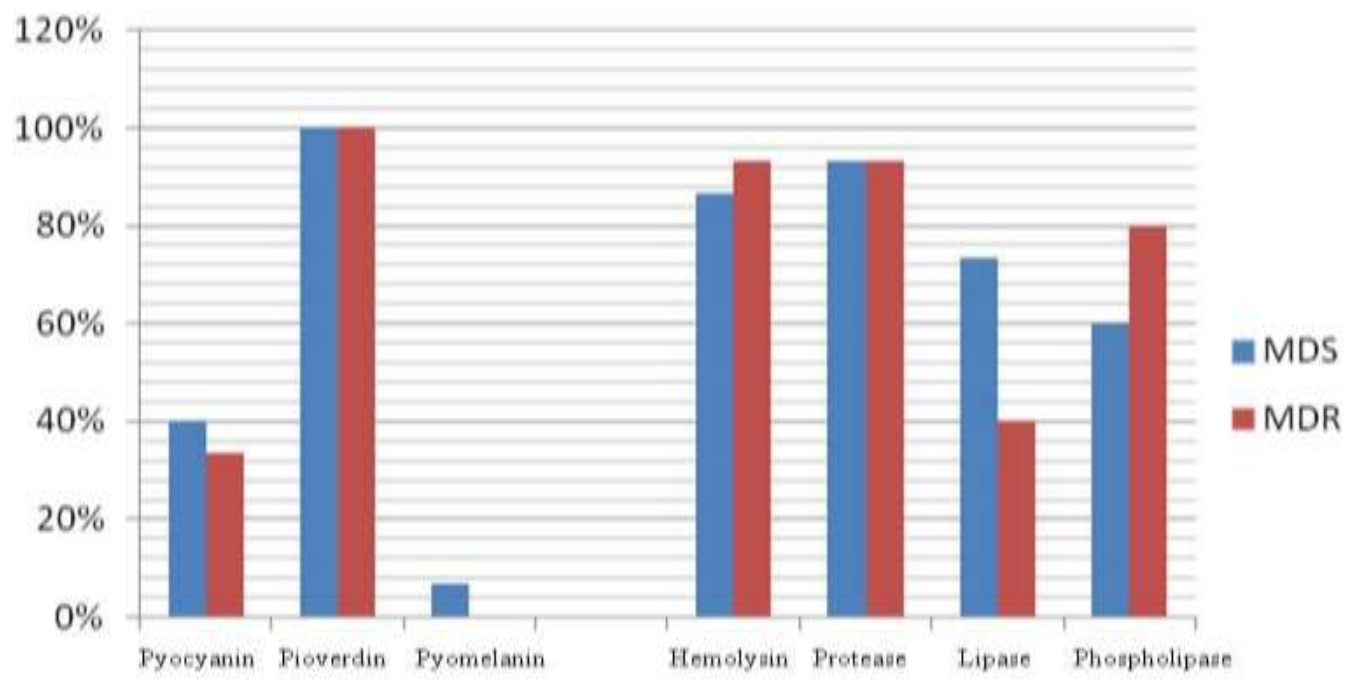

Source: Authors.

\section{Virulence Genes Distribution}

The results in Figure 4 show the frequency distribution of virulence genes according to the resistance pattern. The MDS isolates obtained a $20 \%$ higher frequency of the toxA and las $A$ genes, than the MDR isolates, all isolates in the study had the $l a s B$ and $p l c H$ genes. 
Figure 4: Virulence genes frequency of clinical isolates of $P$. aeruginosa comparing the resistance profile MDS and MDR.

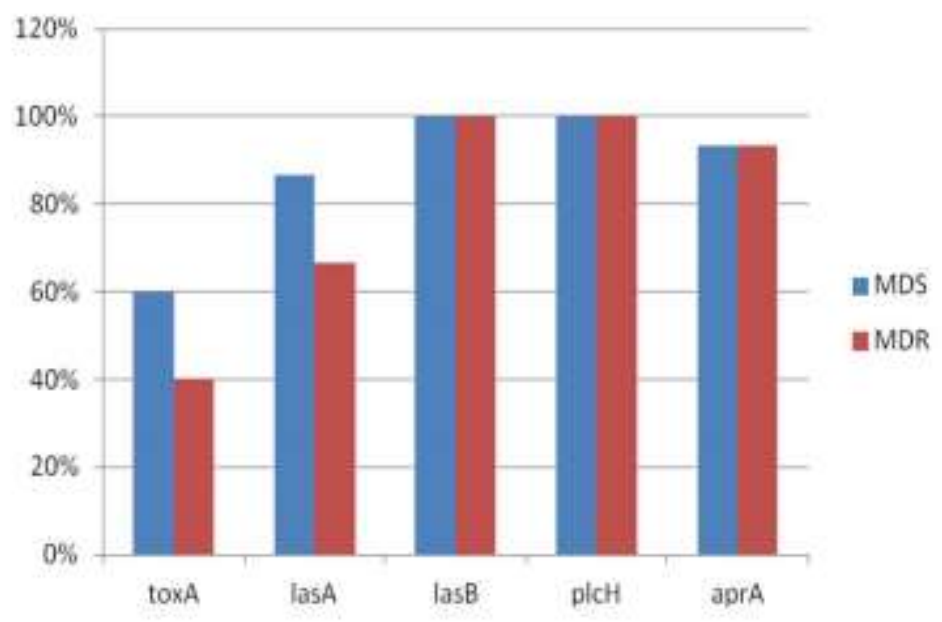

Source: Authors.

\section{Genetic Relation}

The molecular typing of the isolates revealed 28 genetic profiles, with the occurrence of two isolates showing a clonal relationship, Figure 5, is the representation of the genetic similarity dendrogram among all $P$. aeruginosa isolates estimated by the ERIC-PCR technique. 
Research, Society and Development, v. 10, n. 11, e457101120032, 2021

(CC BY 4.0) | ISSN 2525-3409 | DOI: http://dx.doi.org/10.33448/rsd-v10i11.20032

Figure 5: Molecular typing for clinical isolates $M D S$ and $M D R$ of $P$. aeruginosa.

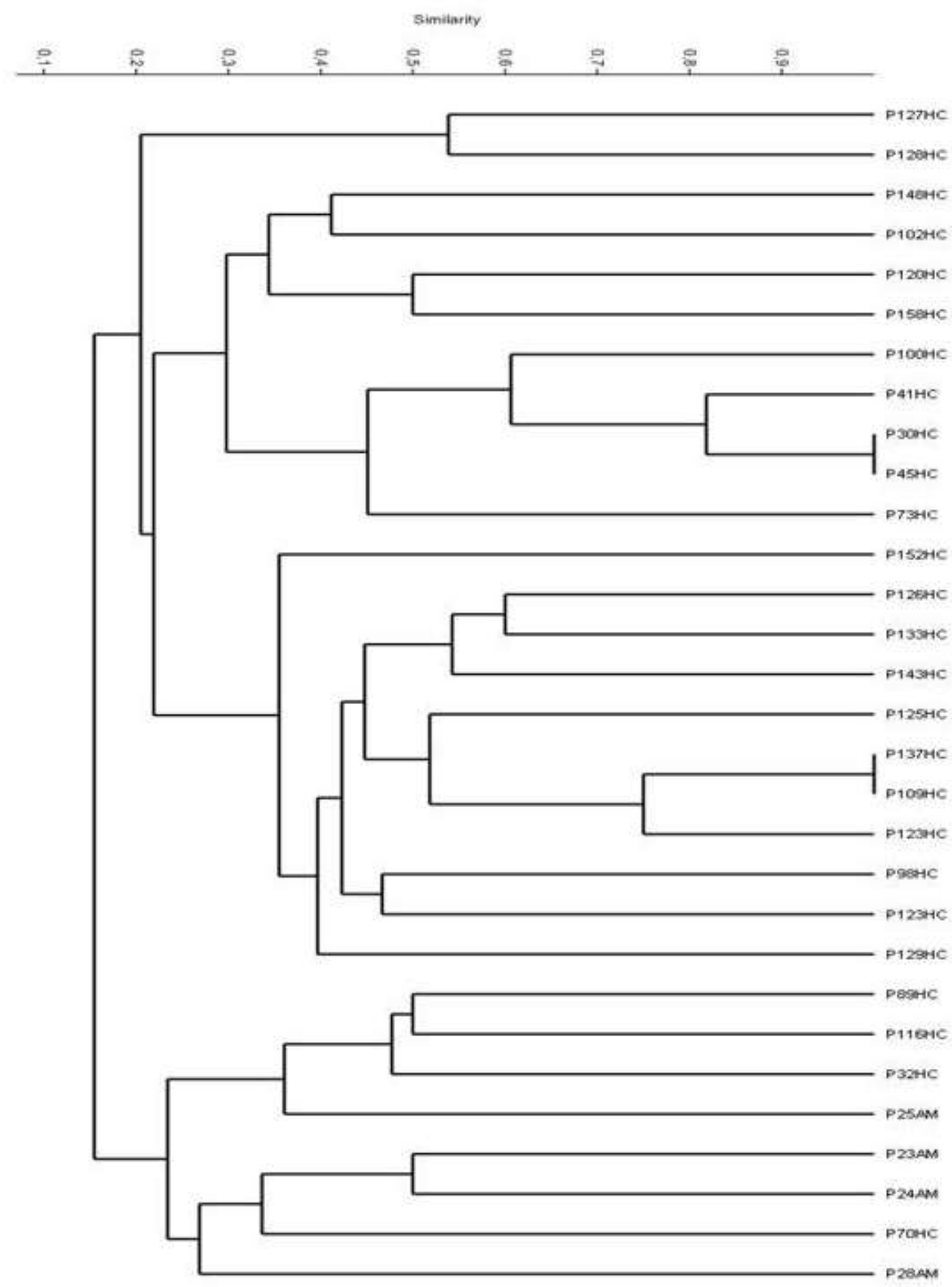

Source: Authors.

The Figures 6 A and B show dendrograms of genetic similarity between MDS and MDR isolates, respectively, where it is possible to see that the mentioned clones were found among MDR isolates. 
Figure 6: A - Molecular typing for clinical isolates MDS of $P$. aeruginosa and B - Molecular typing for clinical isolates MDR of $P$. aeruginosa.
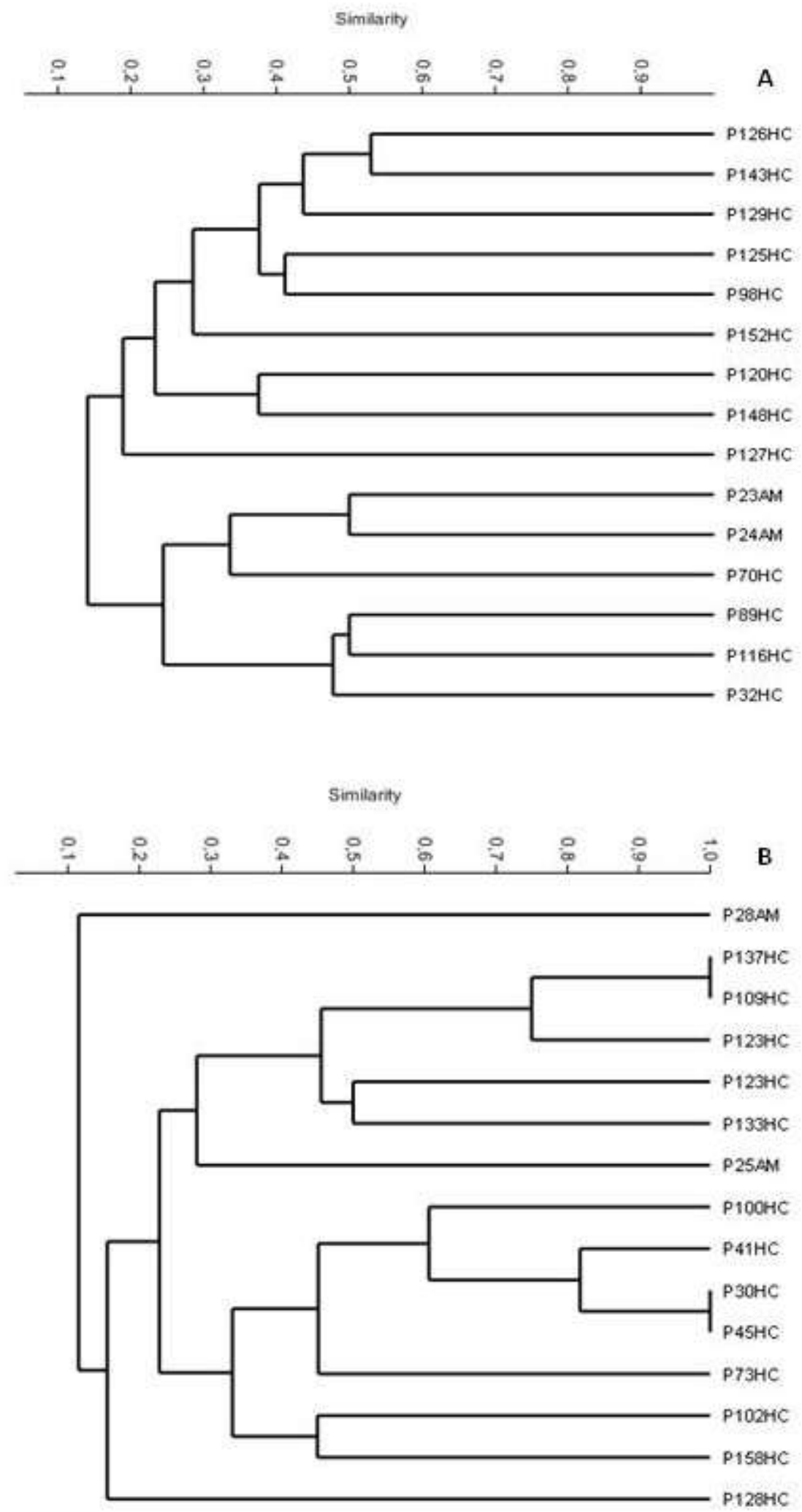

Source: Authors. 


\section{Discussion}

In this study, there was high resistance for cephalosporins among the isolates of P. aeruginosa studied. These antimicrobials are used in the treatment of serious infections, such as septicemia caused by this pathogen (Pérez et al., 2012). The tendency toward less sensitivity to cephalosporins has been described in other regions of Brazil; this might be due to the large-scale use of this drug as a therapeutic option, for many years, for patients with various infections in public hospitals (Jácome et al., 2016; Siqueira et al., 2018; Furtado et al., 2019; Ribeiro et al., 2020).

The isolates in these studies had low resistance to carbapenems; however, with temporal evolution, this frequency has increased, as described by Jácome et al. (2016) and Lima et al. (2020), reaching 53\% and 40\%, respectively, among hospital isolates from Recife-PE. The MDR isolates exhibited a lower frequency of resistance to aminoglycosides; this has also been verified in the studies of Siqueira et al. (2018) and Montoro et al. (2019). The great diversity presented in the susceptibility profile to the antimicrobial classes suggests the existence of an association of several resistance mechanisms, which was beyond the scope of this study.

The MDS/MDR isolates analyzed in this study were most prevalent in tracheal secretions of patients admitted to Intensive Care Units (ICUs). This result is not surprising, since P. aeruginosa is one of the main microorganisms related to infections in patients having pneumonia and requiring mechanical ventilation (Sader et al., 2015).

An analysis of the production of virulence factors among the isolates in this study indicated a higher production of pyocyanin in the MDS isolates, favoring pathogenesis by these microorganisms; this was also observed by Deptuła and Gospodarek (2010) and El-Mahdy and El-Kannishy (2019). Overexpression of pyocyanin was detected in different samples of airway secretions from patients colonized by $P$. aeruginosa and was associated with the severity of the disease and a decrease in lung function (Rada \& Leto, 2013). Silva et al. (2014) on the other hand, described an increase in the production of pyocyanin in isolates from urinary tract infections.

Related of production of pigments and other virulence factors in isolates of $P$. aeruginosa, the study by Finlayson and Brown (2011), described that in the pigmented (production of pyocyanin and/or pyoverdin) isolates of $P$. aeruginosa from different clinical samples there was more production of elastase, protease and lipase than non-pigmented isolates, in the present study, all the isolates MDR or MDR presented some type of pigment, which may be related with a high frequency of other virulence factors.

Hemolysin production was high among the isolates of both groups. Hemolytic phospholipase $\mathrm{C}$ and ramnolipids are hemolysins produced by $P$. aeruginosa (Ostroff, Vasil \& Vasil, 1990). In this study, the plcH gene was detected in all the isolates, however, nine isolates did not show phenotypic production of phospholipase $\mathrm{C}$, which may have been due to the regulation of gene expression (Heidary et al., 2016).

Furthermore, proteases, another type of virulence factor produced by $P$. aeruginosa that helps in its pathogenesis, were widely detected among MDS and MDR isolates. These data corroborate those presented by Deptuła and Gospodarek (2010), who observed no difference between the groups analyzed. Shigematsu et al. (2001) carried out in vitro studies on $P$. aeruginosa and demonstrated that the protease enzyme is expressed in environments with free-iron deficiency, is important in the acquisition of iron at the site of the infectious process and favors bacterial virulence. We found two isolates that did not show proteolytic activity in the phenotypic test and were negative for the aprA gene.

Most of the isolates in this study secreted the enzyme elastase B (LasB), an elastolytic metalloproteinase that is encoded by the lasB gene (Nikbin et al., 2012). In addition to damaging tissues, LasB is capable of degrading components of the innate and acquired immune system, including cytokines and antimicrobial peptides (Kuang et al., 2011). In this study, las $A$ and lasB genes were detected at a lower frequency among MDR isolates compared to MDS isolates, corroborating the 
data of Deptuła and Gospodare (2010) and El-Mahdy and El-Kannishy (2019), however, it is necessary to remember that both las $A$ and las $B$ are regulated by quorum sensing, and hence, that their expression varies greatly depending on the regulation.

Another gene with higher occurrence among MDS isolates was the toxA gene, which is a structural component of exotoxin A. This enzyme is a determinant virulence factor of $P$. aeruginosa and is considered the most toxic and potent among other virulence mechanisms (Hassuna, Mandour \& Mohamed, 2020). Some reports state that there is a relationship between las $B$ and toxA genes in strains isolated from the lungs of patients with cystic fibrosis, in which the transcripts of these genes are regulated more in bacterial cells (Storey et al., 1997). Moreover, LasB is a well-studied virulence factor that minimizes the immune response and is the target of alveolar macrophages (Andrejko et al., 2013).

The results obtained in this study demonstrated a correlation only for some of the studied virulence factors, suggesting that this relationship is multifactorial. The MDR isolates produced less pyocyanin and lipase, and exhibited lower expression of the toxA and lasA genes, whereas the MDS isolates produced less hemolysin and phospholipase C. It has been reported that the acquisition of virulence factors by MDR bacteria during the infectious process can lead to unnecessary metabolic costs for the microorganism (Sanchez et al., 2002) and that the addition of resistance mechanisms leads to a decrease in virulence factors (Deptuła \& Gospodarek, 2010). This relationship between virulence and resistance in P. aeruginosa has not been established in this study, some authors as Al Dawodeyah et al. (2018) indicated that there is association between antimicrobial resistance and virulence genes in MDR strains and Persyn et al., 2019, refers this association is poorly understood.

The genetic profile in this study showed a great diversity; with a total of 30 isolates, it was possible to observe 28 genetic profiles. Clones were present among the MDR isolates; interestingly, the clones, P137HC and P109HC, showed discordant results in the test of hemolysin production, whereas $\mathrm{P} 30 \mathrm{HC}$ and $\mathrm{P} 45 \mathrm{HC}$ showed discordant results for the production of phospholipase $\mathrm{C}$. These results may have resulted from the regulation of gene expression, which was beyond the scope of this study, since $P$. aeruginosa has quorum sensing systems that are responsible for regulating the expression of $p l c H$ (hemolytic phospholipase C), ramnolipids, and other virulence factors, which would explain such phenotypic differences (Strateva \& Mitov, 2011).

The presence of these patterns of virulence in almost all the isolates studied highlights the high level of pathogenicity of isolates derived from nosocomial infections. Therefore, $P$. aeruginosa is a pathogen capable of accumulating numerous virulence factors, and in some cases, is associated with multidrug resistance, which makes it difficult to treat infections caused by it.

\section{Conclusion}

In conclusion, a tendency described by several authors, that is, a decrease in virulence factors with an increase in resistance to antimicrobials, was observed in relation to the toxA and lasA genes and in the production of lipase and pyocyanin. This shows that the acquisition of virulence factors can lead to unnecessary metabolic expenditure for MDR isolates.

\section{Acknowledgments}

We offer our deepest thanks to the institutions that provided technical support for the development and implementation of this study.

This work was financially supported by a Conselho Nacional de Desenvolvimento Científico e Tecnológico (CNPq) grant to M.A.V.M. (process no. 474777/2013-8). We declare that there are no conflicts of interest. This study was approved by the Ethics Committee on Research of the Federal University of Pernambuco (CEP/CCS/UFPE - Comitê de Ética em Pesquisa/Centro de Ciências da Saúde/Universidade Federal de Pernambuco), CAAE number 0490.0.172.000-11. 


\section{References}

Al Dawodeyah, H. Y., Obeidat, N., Abu-Qatouseh, L. F., Shehabi, A. A. (2018). Antimicrobial resistance and putative virulence genes of Pseudomonas aeruginosa isolates from patients with respiratory tract infection. Germs, 8(1), 31-40. 10.18683/germs.2018.1130.

Andrejko, M., Zdybicka-Barabas, A., Janczarek, M., Cytryńska, M. (2013). Three Pseudomonas aeruginosa strains with different protease profiles. Acta Biochimica Polonica, 60(1):83-90. 10.18388/abp.2013_1955.

CLSI (Clinical and Laboratory Standards Institute). (2015). Performance standards for antimicrobial susceptibility testing, twenty-fifth informational supplement, document M100-S25.Wayne, PA, USA. 2015.

Deptuia, A \& Gospodarek, E. (2010). Reduced expression of virulence factors in multidrug-resistant Pseudomonas aeruginosa strains. Archives of Microbiology, 192(1), 79-84. 10.1007/s00203,3-009-0528-1.

Duan, H., Chai, T., Liu, J., Zhang, X., Qi, C., Gao, J. et al. (2009). Source identification of airborne Escherichia coli of swine house surroundings using ERICPCR and REP-PCR. Environmental Research, 109(5), 511-517. 10.1016/j.envres.2009.02.014.

El-Mahdy, R. \& El-Kannishy, G. (2019). Virulence Factors of Carbapenem-Resistant Pseudomonas aeruginosa in Hospital-Acquired Infections In Mansoura, Egypt. Infection and Drug Resistance, 7(12), 3455-3461. 10.2147/IDR.S222329.

Finlayson, E. A. \& Brown, P. D. (2011). Comparison of Antibiotic Resistance and Virulence Factors in Pigmented and Non-pigmented Pseudomonas aeruginosa. The West Indian Medical Journal, 60(1), 24-32.

Furtado, D. M. F., Silveira, V. S., Carneiro, I. C. R. S., Furtado, D. M. F., Kilishekl, M. P. (2019). Consumo de antimicrobianos e o impacto na resistência bacteriana em um hospital público do estado do Pará, Brasil, de 2012 a 2016. Revista Pan-Amazônica de Saúde, 10, e201900041. 10.5123/s21766223201900041 .

Habermann, E. \& Hardt, K. L. (1972). A sensitive and specific plate test for the quantitation of phospholipases. Analytical Biochemistry, 50(1), 163-173. 10.1016/0003-2697(72)90495-2.

Hassuna, N. A., Mandour, S. A. \& Mohamed, E. S. (2020). Virulence Constitution of Multi-Drug-Resistant Pseudomonas aeruginosa in Upper Egypt. Infection and Drug Resistance, 13:587-595. 10.2147/IDR.S233694.

Heidary, Z., Bandani, E., Eftekhary, M., Jafari, A. A. (2016). Virulence Genes Profile of Multidrug Resistant Pseudomonas aeruginosa Isolated from Iranian Children with UTIs. Acta Medica Iranica, 54(3), 201-210.

Jácome, P. R. L. A., Alves, L. R., Cabral, A. B., Lopes, A. C. S., Maciel, M. A. V. (2012). Phenotypic and molecular characterization of antimicrobial resistance and virulence factors in Pseudomonas aeruginosa clinical isolates from Recife, State of Pernambuco, Brazil. Revista da Sociedade Brasileira de Medicina Tropical, 45(6), 707-712. 10.1590/s0037-86822012000600010.

Jácome, P. R. L. A., Alves, L. R., Jácome-Júnior, A. T., Silva, M. J. B., Lima, J. L. C., Araújo, P. S. R. et al. (2016). Detection of blaSPM-1, blaKPC, blaTEM and blaCTX-M genes in isolates of Pseudomonas aeruginosa, Acinetobacter spp. and Klebsiella spp. from cancer patients with healthcare-associated infections. Journal of Medical Microbiology, 65(7), 658-665. 10.1099/jmm.0.000280.

Jagger, K. S., Bahner, D. R. \& Warren, R. L. (1983). Protease phenotypes of Pseudomonas aeruginosa isolated from patients with cystic fibrosis. Journal of Clinical Microbiology, 17(1), 55-59. 10.1128/jcm.17.1.55-59.1983.

Janda, J. M. \& Bottone, E. J. (1981). Pseudomonas aeruginosa enzyme profiling: predictor of potential invasiveness and use as an epidemiological tool. Journal of Clinical Microbiology, 14(2), 55-60. 10.1128/jcm.14.1.55-60.1981.

Kuang, Z., Hao, Y., Walling, B. E., Jeffries, J. L., Ohman, D. E., Lau, G. W. (2011). Pseudomonas aeruginosa elastase provides an escape from phagocytosis by degrading the pulmonary surfactant protein-A. PLoS One, 6(11), e27091. 10.1371/journal.pone.0027091.

Lanotte, P., Watt, S., Mereghetti, L., Dartiguelongue, N., Rastegar-Lari, A., Goudeau, A. et al. (2004). Genetic features Pseudomonas aeruginosa isolates from cystic fibrosis patients compared with those of isolates from other origins. Journal of Medical Microbiology, 53(1), 73-81. 10.1099/jmm.0.05324-0.

Lima, A. V. A., Silva, S. M., Nascimento Júnior, J. A. A., Correia, M. T. S., Luz, A. C., Leal-Balbino, T. C. et al. (2020). Occurrence and Diversity of Intra- and Interhospital Drug-Resistant and Biofilm-Forming Acinetobacter baumannii and Pseudomonas aeruginosa. Microbial Drug Resistance, 26(7), 802-814. $10.1089 / \mathrm{mdr} .2019 .0214$.

Lomholt, J.A., Poulsen, K. \& Kilian, M. (2001). Epidemic population structure of Pseudomonas aeruginosa: evidence for a clone that is pathogenic to the eye and that has a distinct combination of virulence factors. Infection and Immunity, 69 (10), 6284-6295. 10.1128/IAI.69.10.6284-6295.2001.

Lupo, A., Haenni, M. \& Madec, J. Y. (2018). Antimicrobial Resistance in Acinetobacter spp. and Pseudomonas spp. Microbiology Spectrum, 6(3). 10.1128/microbiolspec.ARBA-0007-2017.

Magiorakos, A. P., Srinivasan, A., Carey, R. B., Carmeli, Y., Falagas, M. E., Giske, C. G. et al. (2012). Multidrug-resistant, extensively drug-resistant and pandrug-resistant bacteria: an international expert proposal for interim standard definitions for acquired resistance. Clinical Microbiology and Infection, 18(3), 268-281. 10.1111/j.1469-0691.2011.03570.x.

Montoro, C. P., Aragón, J. R., Rubio, C. M., Martín, S. G., Carrillo, C. F., Iglesias, M. A. R. (2019). Evaluación de la sensibilidad de cepas de Pseudomonas aeruginosa multi-resistentes frente a ceftolozano/tazobactam. Revista Chilena de Infectologia, 36(5), 551-555. 10.4067/S0716-10182019000500551.

Nikbin, V., Aslani, M.M., Sharafi, Z., Hashemipour, M., Shahcheraghi, F., Ebrahimipour, G. (2012). Molecular identification and detection of virulence genes among Pseudomonas aeruginosa isolated from different infectious origins. Iranian Journal of Microbiology, 4(3), 118-123. 
Ostroff, R. M., Vasil, A. I. \& Vasil, M. L. (1990). Molecular comparison of a nonhemolytic and a hemolytic phospholipase C from Pseudomonas aeruginosa. Journal of Bacteriology, 172(10), 5915-5923. 10.1128/jb.172.10.5915-5923.1990.

Paz-Zarza, V. M., Mangwani-Mordani, S., Martínez-Maldonado, A., Álvarez-Hernández, D., Solano-Gálvez, SG, Vázquez-Lopez, R. (2019). Pseudomonas aeruginosa: pathogenicity and antimicrobial resistance in urinary tract infection. Revista Chilena de Infectologia, 36(2), 180-189. 10.4067/s071610182019000200180

Pérez, A. C., Torres, R. F., Ramos, C. M. S., Núnez, G. C. (2012). Ceftazidima en infusión continua en infecciones por Pseudomona aeruginosa. AMC Revista Archivo Médico De Camagüey, 16(4):408-418.

Persyn, E., Sassi, M., Aubry, M., Broly, M., Delanou, S., Asehnoune, K., Caroff, N., Crémet, L. (2019). Rapid genetic and phenotypic changes in pseudomonas aeruginosa clinical strains during ventilator associated pneumonia. Scientific Reports, 9(1), 4720. 10.1038/S41598-019-41201-5.

Rada, B. \& Leto, T. L. (2013). Pyocyanin effects on respiratory epithelium: relevance in Pseudomonas aeruginosa airway infections. Trends in Microbiology, 21(2), 73-81. 10.1016/j.tim.2012.10.004.

Ribeiro, A. C. S., Crozatti, M. T. L., Silva, A. A., Macedo, R. S., Machado, A. M. O., Silva, A. T. A. (2020). Pseudomonas aeruginosa in the ICU: prevalence, resistance profile, and antimicrobial consumption. Revista da Sociedade Brasileira de Medicina Tropical, 53, e20180498, 10.1590/0037-8682-0498-2018.

Sader, H. S., Castanheira, M., Flamm, R. K., Mendes, R. E., Farrell, D. J., Jones, R. N. (2015). Cefazidime/avibactam tested against Gram-negative bacteria from intensive care unit (ICU) and non-ICU patients, including those with ventilator-associated pneumonia. International Journal of Antimicrobial Agents, 46(1), 5359. 10.1016/j.ijantimicag.2015.02.022.

Sanchez, P., Linares, J.F., Ruiz-Díez, B., Campanario, E., Navas, A., Baquero, F., Martinez, J.L. (2002). Fitness of in vitro selected Pseudomonas aeruginosa $n a l B$ and $n f x B$ multidrug resistant mutants. The Journal of Antimicrobial Chemotherapy, 50(5), 657-664. 10.1093/jac/dkf185.

Shigematsu, T., Fukushima, J., Oyama, M., Tsuda, M., Kawamoto, S., Okuda, K. (2001). Iron-mediated regulation of alkaline proteinase production in Pseudomonas aeruginosa. Microbiology and Immunology, 45(8), 579-590. 10.1111/j.1348-0421. 2001.tb01289.x.

Silva, L. V., Galdino, A. C. M., Nunes, A. P. F., Santos, K. R. N., Moreira, B. M., Cacci, L. C. et al. (2014). Virulence attributes in Brazilian clinical isolates of Pseudomonas aeruginosa. International Journal of Medical Microbiology, 304(8), 990-1000. 10.1016/j.ijmm.2014.07.001.

Silva Júnior, V. V., Ferreira, L. D., Alves, L. R., Cabral, A. B., Jácome, P. R. L. A., Araújo, P. S. R. et al. (2017). Detection of multidrug-resistant Pseudomonas aeruginosa harboring blaGES-1 and blaGES-11 in Recife, Brazil. Revista da Sociedade Brasileira de Medicina Tropical, 50(6), 764-768. $10.1590 / 0037-8682-0532-2016$.

Siqueira, C. C. M., Guimarães, A. C., Mata, T. F. D., Pratte-Santos, R., Raymundo, N. S. L., Dias, C. F. et al. (2018). Prevalence and antimicrobial susceptibility profile of microorganisms in a university hospital from Vitória (ES), Brazil. Jornal Brasileiro de Patologia e Medicina Laboratorial, 54(2), 76-82. $10.5935 / 1676-2444.20180014$.

Storey, D. G., Uujack, E. E., Mitchel, I., Rabin, H. R. (1997). Positive correlation of algD transcription to lasB and lasA transcription by populations of Pseudomonas aeruginosa in the lungs of patients with cystic fibrosis. Infection and Immunity, 65(10), 4061-4067. 10.1128/iai.65.10.4061-4067.1997.

Strateva, T. \& Mitov, I. (2011). Contribution of an arsenal of virulence factors to pathogenesis of Pseudomonas aeruginosa infections. Annals of Microbiology, 61:717-732. 10.1007/s13213-011-0273-y.

Todar, K. (2020). Todar's online Textbook of bacteriology. <http://www.textbookofbacteriology.net/pseudomonas.html.>.

Wang, H., Tu, F., Gui, Z., Lu, X., Chu, W. (2013). Antibiotic Resistance Profiles and Quorum Sensing-Dependent Virulence Factors in Clinical Isolates of Pseudomonas aeruginosa. Indian Journal of Microbiology, 53(2), 163-167. 10.1007/s12088-013-0370-7.

Winn Jr, W. C., Allen, S. D., Janda, W. M., Koneman, E., Procop, G., Schreckenberger, P. C., Woods, G. (2008). Bacilos gram-negativos não fermentadores. Koneman Diagnostico Microbiologico, Texto e Atlas colorido. (6a ed.), Guanabara Kooggan, Brasil, 302-386. 